\title{
FAKTOR YANG MEMBERATKAN HUKUMAN TERHADAP PELAKU TINDAK PIDANA PERKOSAAN \\ (Studi Kasus di Pengadilan Negeri Padangsidimpuan)
}

\author{
MARWAN BUSYRO \\ Universitas Muhammadiyah Tapanuli Selatan \\ Email : marwan.busyro@um-tapsel.ac.id
}

\begin{abstract}
Abstrak
Adapun materi yang disajikan dalam penelitian ini adalah Faktor Yang Memberatkan Hukuman Terhadap Pelaku Tindak Pidana Perkosaan Studi Kasus Di Pengadilan Negeri Padangsidimpuan berdasarkan materi yang akan diteliti tersebut di atas bahwasanya para pelaku-pelaku tindak pidana perkosaan seharusnya dapat dijatuhi dengan hukuman yang memberatkan, maka dengan demikian perlu diteliti faktor yang memebratkan hukumannya. Berdasarkan pengamatan tersebut di atas penulis mengangkat permasalahan dalam penelitian adalah apakah faktor yang memberatkan hukuman terhadap pelaku tindak pidana perkosaan di Pengadilan Negeri Padangsidimpuan dan apakah pertimbangan Hakim dalam menentukan hukuman pemberatan terhadap pelaku tindak pidana perkosaan di Pengadilan Negeri Padangsidimpuan?

Sedangkan tujuan penelitian adalah untuk mengetahui faktor yang memebratkan hukuman terhadap pelaku tindak pidana perkosaan di Pengadilan Negeri Padangsidimpuan sesuai dengan Putusan Pengadilan Nomor : 599/Pid.B/2008/PN.Psp.Gnt dan untuk mengetahui pertimbangan Hakim dalam menentukan hukuman dengan pemebratan terhadap pelaku tindak pidana perkosaan di Pengadilan Negeri Padangsidimpuan

Selanjutnya metode penelitian yang penulis gunakan dalam penulisan penelitian ini adalah penelitian deskriptif yang maksudnya adalah penelitian yang dilakukan dengan hasil wawancara penulis dengan responden dan juga melakukan penelitian terhadap data-data maupun berkas-berkas yang berkaitan dengan penelitian dengan cara melakukan Penelitian Lapangan (Library Research) dan Penelitian Kepustakaan (Field Research).
\end{abstract}

Kata Kunci :Hukuman, Pelaku, Tindak Pidana Perkosaan

\section{PENDAHULUAN}

Latar Belakang Masalah

Apabila kita perhatikan tingkat kejahatan dewasa ini dapat kita lihat sesuai dengan kenyataan yang terjadi bahwa baik secara kwalitas maupun kwantitasnya menunjukkan titik yang meresahkan masyarakat dengan modus operandi untuk melakukan suatu kejahatan yang beraneka ragam. Demikian juga halnya jika ditinjau dari sudut pelakunya maupun sebagai korban terus mengalami perkembangan, akalau dari sisi pelaku tindak pidana perkosaan yang terjadi dilingkungan masyarakat baik yang terdapat di perkotaan maupun di pedesaan sangat meresahkan sekali apabila terjadinya suatu tindak pidana perkosaan yang dilakukan secara paksa terhadap korban.

Berdasarkan dengan penjelasan tersebut di atas sebagai contoh bentuk 


\section{MUQODDIMAH}

kejahatan yang terjadi dilingkungan masyarakat adalah seperti dalam studi kasus penelitian yang dilakukan penulis yaitu dengan Putusan Nomor : 599/Pid.B/2008/PN.Psp.Gnt , dimana secara yuridis formalnya maupun di dasarkan terhadap norma-norma yang berlaku ditengah-tengah masyarakat benar-benar suatu perbuatan yang cukup keji dan tidak bermoral apalagi pelaku melakukannya terhadap seseorang yang bukan istrinya dengan secara kekerasan ataupun dengan ancaman kekerasan terhadap korban.

Berdasarkan penjelasan tersebut di atas maka penulis tertarik untuk mengangkat suatu judul penelitian yaitu "Faktor Yang Memberatkan Hukum Terhadap Pelaku Tindak Pidana Perkosaan (Studi Kasus Di Pengadilan Negeri Padangsidimpuan)".

\section{Perumusan Masalah}

Sebagaimana dijelaskan di atas dan kita ketahui bahwa tindak pidana perkosaan dalam proses persidangan dilaksanakan secara tertutup untuk umum, hal ini disebabkan adanya unsur kesusilaan baik pelaku sendiri maupun korban akan tidak leluasa untuk menerangkan peristiwa yang terjadi secara hakiki. Sebelum penulis mengemukakan apa rumusan permasalahan yang diambil dalam penelitian ini terlebih dahulu akan dijelaskan pengertian dari pada perumasalah sebagaimana yang dukemukakan oleh Sumadi Suryabrata yaitu : "Kalau ada kesenjangan (gap) antara das sollen dengan das das sain, ada perbedaan antara yang seharusnya dan apa yang ada dalam kenyataan, antara yang diperlukan dan apa yang tersedia, antara harapan dan kenyataan dan sejenisnya dengan itu" (Sumadi Suryabrata, 1981: 66)

Berdasarkan pengertian permasalahan yang dijelaskan tersebut di atas, maka penulis akan merumuskan permasalahan yang dihadapi dalam penelitian ini yaitu :

1. Apakah faktor yang memberatkan hukuman terhadap pelaku tindak pidana perkosaan di Pengadilan Negeri Padangsidimpuan?

2. Apakah pertimbangan Hakim dalam menentukan hukuman pemberatan terhadap pelaku tindak pidana perkosaan di Pengadilan Negeri Padangsidimpuan?

\section{Tujuan Penelitian}

Dengan demikian sebelum penulis mengemukakan tujuan penelitian dalam penulisan penelitian ini, jika kita melihat bahwasanya dalam hal tindak pidana perkosaan khususnya di Negara kita maupun di daerah kita sudah sering terdapat adanya perbuatan-perbuatan tindak pidana baik tindak pidana pencurian maupun perkosaan yang mengakibatkan kerugian bagi para korban yang mengalaminya, maka sesuai dengan hal tersebut penulis akan membahas tentang tindak pidana perkosaan yang akan dituangkan di dalam penelitian ini, sejalan dengan penjelasan tersebut maka penulis akan mengemukakan beberapa tujuan penelitian yang akan dirumuskan di bawah ini yaitu :

1. Untuk mengetahui faktor yang memebratkan hukuman terhadap pelaku tindak pidana perkosaan di Pengadilan Negeri Padangsidimpuan

2. Untuk mengetahui pertimbangan Hakim dalam menentukan hukuman dengan pemebratan terhadap pelaku tindak pidana perkosaan di Pengadilan Negeri Padangsidimpuan

\section{Manfaat Penelitian}

Dalam hal untuk melaksanakan penelitian kita harus mengetahui bahwasanya dalam suatu penelitian itu harus ada manfaatnya bagi kita sesuai 
dengan apa yang pelajari di dalam Fakultas Hukum yang telah mengakhiri perkuliahan, bahwasanya mahasiswa itu akan diwajibkan untuk menyusun suatu karya ilmiah atau dengan kata lain sebuah penelitian yang sesuai dengan topik dan permasalahan yang dirumuskan. Sesuai dengan penjelasan tersebut di atas maka disini penulis akan mengemukakan manfaat dilakukannya suatu penelitian bagi penulis sendiri yaitu

1. Manfaat Teoritis sesuai dengan rumusan masalah yang diangkat dalam penelitian ini penulis ingin mengetahui faktor yang dapat

2. memberatkan hukuman terhadap pelaku tindak pidana perkosaan yang sesuai dengan Putusan Nomor 599/Pid.B/2008/PN.Psp.Gnt

3. Manfaat Praktis agar penulis dapat menjelaskan kepada lapisan masyarakat apabila terjadi pemerkosaan terhadap keluarganya supaya mengetahui bahwasanya tindaka pidana kejahatan tersebut sudah merugikan terhadap para korban karena sudah melanggar norma kesusilaan dan norma hukum yang berlaku.

\section{Kajian Teoritis \\ Pengertian Kejahatan Dalam Hukum Pidana}

Selanjutnya penulis akan menguraikan tentang pengertian kejahatan dalam hukum pidana, dimana kita mengetahui bahwa di dalam masyarakat modren yang multi konflek sekarang banyak sekali persaingan hidup dan tidak sedikit menimbulkan tuntutan yang sebab kontradiktif antara suatu kepentingan dengan kepentingan lainnya sehingga keadaan ini memperbanyak pola tingkah laku yang abnormal di tengah-tengah masyarakat. Dikatakan demikian sebagai tingkah laku yang abnormal seperti dijelaskan di atas karena merupakan suatu tindakan yang menyimpang dari aturan Undang-undang serta dapat menimbulkan kerugian bagi masyarakat, maka secara teoritisnya prilaku abnormal tersebut dalam IImu Pengetahuan Hukum Pidana disebut dengan kejahatan. Sejalan dengan penjelasan tersebut di atas dimana para ahli hukum menjelaskan tentang defenisi tentang pengertian kejahatan seperti yang dikemukakan oleh D. Soedjono yaitu : "Kejahatan adalah pelanggaran norma yang ditafsirkan atau patut ditafsirkan sebagai perbuatan yang merugikan, menjengkelkan dan tidak boleh dibiarkan.(D. Soedjono,1983:18)

Sesuai dengan kutipan yang dikemukakan penulis di atas adanya juga yang menjelaskan bahwa kejahatan itu dapat diartikan dalam arti yuridis sebagaimana yang dikemukakan oleh Abdulsyani yaitu : "Kriminalitias ditinjau dari arti yuridis ialah jika seseorang melanggar peraturan atau Undangundang pidana dan ia dinyatakan bersalah oleh Pengadilan serta dijatuhi hukuman berarti seseorang tersebut belum dianggap sebagai pelaku. (Abdulsyani, 1987:11)

Berdasarkan pendapat sarjana tersebut di atas tentang pengertian suatu kejahatan Hermien Hadiati Koeswadji menegaskan kembali pengertian suatu kejahatan yaitu : "Kejahatan ataupun yang disebut dengan delik merupakan perbuatan pidana yaitu perbuatan yang dularang oleh suatu aturan hukum, larangan mana disertai ancaman (sanksi) yang berupa pidana tertentu bagi barang siapa yang melanggar larangan tersebut (Hermien Hadiati Koeswadji, 1984:48)

Selanjutnya dalam hal pengertian kejahatan sebagai perbandingannya sebagaimana dijelaskan oleh J. E. Sahetapy yang menyatakan bahwa kehatan itu adalah : 
MUQODDIMAH

Kejahatan adalah setiap perbuatan (Setiap Kelakuan) yang dilarang oleh Hukum Publik untuk melindungi masyarakat dan diberi sanksi yang berupa pidana oleh Negara, perbuatan tersebut diberi hukuman pidana karena melanggar normanorma sosial masyarakat mengenai yingkah laku yang patut dari seorang warga Negara (J.E. Sahetapy, 1991: 20)

Sesuai dengan penjelasan tersebut di atas maka untuk dapat digolongkan sebagai perbuatan yang dapat dihukum oleh ketentuan hukum pidana seperti yang dijelaskan oleh $R$, Soesilo di dalam penjelasan Kitab Undang-undang Hukum Pidana mengatakan : "Tiada suatu perbuatan yang dapat di pidana melainkan atas kekuatan ketentuan pidana dalam Undang-undang yang berlaku terlebih dahulu dari peristiwa itu" (R. Soesilo, 1974: 27)

Berdasarkan kutipan tersebut di atas apa bila terjadi suatu tindak pidana kejahatan seharusnya mempunyai unsurunsur yang dapat dikategorikan sebagai perbuatan pidana sebagaimana yang dikemukakan oleh Darmansyah Hasibuan berikut ini :

1. Unsur Subyektif, maksudnya harus ada perbuatan yang bertanggung jawab atas kelakuan yang bertentangan dengan hukum itu yang disebut dengan anasir kesalahan

2. Unsur Obyektif, maksudnya harus ada suatu kelakuan atau perbuatan yang bertentangan dengan hukum disebut anasir melawan hokum(Darmansyah Hasibuan, 1980:23).

Sebagaimana ketentuan yang dijelaskan di atas dimana keberadaan azas kesalahan yang berbunyi Gen Straf Zonder Schul yang artinya tidak tanpa adanya kesalahan, jadi menentukan adanya kesalahan atas perbuatan seseorang itu tergantung kepada pertanggung jawaban hukum yang akan dikenakan terhadap pelaku. Selanjutnya sebagaimana yang dijelaskan tersebut di atas dimana ketentuan kejahatan dalam pengertian secara yuridis pada pokoknya terdapat beberapa istilah yang dikemukakan kembali oleh Darmansyah Hasibuan yaitu :

Peristiwa ataupun perbuatan-perbuatan sepreti yang disebut dalam KUHP itu disebut dalam istilah sebagai berikut :

1. Delik (Belanda)

2. Strafbaar Feid (Belanda)

3. Peristiwa Pidana

4. Tindak Pidana

5. Perbuatan yang dapat dihukum

6. Strafbare Handeling (Jerman)

7. Criminal Act (Inggris) (Darmansyah Hasibuan, 1980:11)

Berdasarkan seluruh istilah dalam menyebutkan perbuatan pidana sebagaimana yang terdapat pada literatur hukum pidana pada prinsipnya mengandung arti yang sama yaitu perbuatan yang dilarang oleh aturan Perundang-undangan dimana salah satu diantaranya bentuk pidana itu adalah perkosaan. Selanjutnya apa bila ditinjau dari penjelasan tersebut di atas tentang unsur-unsur kejahatan dimana perbuatan itu supaya dapat dihukum harus mempunyai syarat-syarat sebagaimana yang dikemukakan oleh $A$. Zainal Abidin berikut di bawah ini :

1. Harus terdapat suatu tindakan yang dilarang ataupun yang diwajibkan dalam Undang-undang dimana pelanggaran terhadap larangan atau kewajiban semacam itu telah dinyatakan sebagai tindakan kejahatan yang dapat dihukum

2. Tindakan tersebut harus memenuhi semua unsur delik seperti yang dirumuskan dalam Undang-undang

3. Setiap Strafbaarfeit sebagai suatu pelanggaran terhadap larangan atau 
MUQODDIMAH

kewajiban pada hakekatnya merupakan suatu tindakan melawan hokum(A. Zainal Abidin, 1986: 30).

Berdasarkan uraian di atas jelaslah bahwa tindak pidana dapat diartikan sebagai perbuatan yang oleh aturan hukum pidana atau ancaman dengan hukuman bagi setiap orang yang melanggar dan sebagai sasaran yang menjadi ancaman hukum dimaksud adalah akibat dari suatu tindak pidana yang dilakukan tersebut terhadap orang lain.

\section{Tindak Pidana Perkosaan Dalam Hukum Pidana}

Tindak pidana perkosaan dalam hukum pidana adalah merupakan salah satu bentuk kejahatan yang dilakukan manusia dalam bidang seks yaitu suatu perbuatan berdasarkan hukum pidana yang dikategorikan sebagai delik susila. Sebagaimana di dalam sistematika Kitab Undang-undang Hukum Pidana (KUHP) yang dijelaskan oleh $A$. Zainal Abidin tentang tindak pidana perkosaan terdapat dalam ketentuan buku ke II bab XII khususnya dalam ketentuan Pasal 285 sampai dengan ketentuan Pasal 288 KUHP yang mengatakan sebagai berikut : "Bentuk kejahatan terhadap kesusilaan khususnya tentang tindak pidana perkosaan efek negatifnya dapat menyangkut tiga kepentingan yang meliputi "Kepentingan perorangan" (individuale belangen), kepentingan masyarakat" (sosial belangen) dan kepentingan Negara" (staat belangen)" (A. Zainal Abidin, 1986: 2). Berdasarkan uraian tersebut di atas bahwa tindak pidana perkosaan dalam sistematika hukum pidana ternyata bukan hanya menyangkut kerugian yang bersifat pribadi saja akan tetapi lebih jauh dapat menimbulkan dampak negatif baik terhadap masyarakat maupun terhadap Negara.
Sedangkan pengertian tindak pidana perkosaan dalam ketentuan Pasal 285 Kitab Undang-undang Hukum Pidana $(K U H P)$ adalah sebagai berikut : "Barang siapa dengan kekerasan atau ancaman kekerasan memaksa perempuan yang bukan istirnya bersetubuh dengan dia dihukum karena memperkosa dengan hukuman penjara selama-lamanya dua belas tahun (A. Zainal Abidin, 1986: 2). Selanjutnya tentang pengertian tindak pidana perkosaan sebagaimana yang dikemukakan oleh Moeljatno adalah sebagai berikut : "Barang siapa dengan kekerasan atau ancaman kekerasan memaksa seorang wanita bersetubuh dengan dia diluar perkawinan diancam karena melakukan perkosaan dengan pidana penjara paling lama dua belas tahun (Moeljatno, 1992 : 125).

Berdasarkan pengertian tentang tindak pidana perkosaan tersebut di atas kiranya tindak pidana kejahatan ini diatur dari cara melakukannya harus dengan kekerasan serta persetubuhan tersebut dilakukan diluar perkawinan atau dengan kata lain untuk dapat disebut sebagai tindak pidana perkosaan haruslah dilakukan dengan cara-cara kekerasan terhadap seorang wanita yang bukan istrinya. Sedangkan pendapat lain tentang defenisi tindak pidana perkosaan ini sebagaimana yang dikemukakan oleh H. A. K. Moch Anwar yaitu : "Barang siapa dengan kekerasan atau dengan kekerasan memaksa perempuan yang bukan istrinya bersetubuh dengan dia karena perkosaan, dihukum dengan hukuman penjara selama-lamanya dua belas tahun (H. A. K. Moch Anwar, 1984 : 226).

Sesuai dengan defenisi tersebut di atas dan dibandingkan dengan kedua defenisi sebelumnya dimana pada prinsipnya tidak terdapat perbedaan yang mencolok dari sudut isinya, hanya defenisi tindak pidana perkosaan 


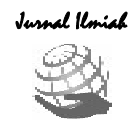

\section{MUQODDIMAH}

tersebut hanya berbeda dari segi redaksi yang mempunyai ciri-ciri khas tersendiri. Sejalan dengan penjelasan tersebut di atas seluruhnya ada baiknya dijelaskan unsur-unsur tindak pidana perkosaan akan diperinci secara satu persatu antara lain :

1. Barang Siapa

Adapun yang dimaksud dengan unsur barang siapa pada ketentuan Pasal 285 KUHP yaitu sebagai tindak pidana perkosaan adalah merupakan perwujudan orang sebagai subjek hukum yang dapat dipertanggung jawabkan atas perbuatan pidana perkosaan yang dilakukan, sebagaimana yang dikemukakan oleh P. A. F. Lamintang bahwa : "Kata barang siapa menunjukkan orang yang apabila orang tersebut memenuhi semua unsur dari tindak pidana yang dimaksudkan dalam ketentuan pasal yang di dakwakan $(\mathrm{H}$. A. K. Moch Anwar, 1984 : 12).

Sebagaimana pendapat sarjana yang tersebut di atas tentang pengertian barang siapa selanjutnya menurut pendapat A. S. Pudjoharsoyo dalam majalah Varia Keadilan mengatakan bahwa : "Unsur barang siapa sudah tentu dimaksudkan manusia dalam hal ini ialah bagi terdakwa sendiri (A. S. Pudjoharsoyo, 1993 : 25).

2. Persetubuhan

Sebagai unsur yang kedua dalam tindak pidana perkosaan adalah tentang apa yang disebut dengan persetubuhan yang mana menurut hukum baru dapat dikatakan sebagai persetubuhan adalah apabila anggota kelamin pria telah masuk ke dalam anggota kelamin/kemaluan wanita dengan sedemikian rupa hingga akhirnya mengeluarkan mani.

3. Dengan Kekerasan

Untuk unsur ketiga dalam membuktikan suatu tindak pidana perkosaan adalah unsur perlakuan yang digunakan terhadap korban yaitu perlakuan tersebut harus dilakukan dengan dasar kekerasan adapun yang dimaksud dengan istilah kekerasan tersebut sebagamana yang dikemukakan oleh R. Sugandhi pada Pasal 89 Kitab Undang-undang Hukum Pidana yaitu :

Arti dari pada melakukan kekerasan ialah menggunakan tenaga atau kekuatan jasmani sekuat mungkin secara tidak syah, misalnya memukul dengan tangan atau dengan segala macam senjata, menyepak, menendang dan sebagainya yang menyebabkan orang yang terkena tindakan kekerasan itu merasa sakit yang sangat (R. Sugandhi, 1981 : 107)

Sesuai dengan kutipan tersebut di atas pengertian kekerasan dapat pula diartikan dengan membuat oraqng menjadi pingsan misalnya hilang ingatan atau tidak sadar serta tidak berdaya yang artinya tidak mempunyai kekuatan atau tenaga sama sekali sehingga tidak mampu mengadakan perlawanan sedikitpun.

\section{Dengan Paksa}

Sebagai unsur yang terakhir dalam tindak pidana perkosaan adalah unsur paksaan yang dilakukan oleh palaku delik terhadap wanita yang akan disetubuhinya tersebut, adapun bentukbentuk unsur paksaan yang dapat digolongkan disini seperti dengan cara merangkul wanita dengan sedemikian rupa dan keras hingga akhirnya tidak dapat mengadakan perlawanan. Berdasarkan seluruh penjelasan tersebut di atas kiranya demikianlah pengrtian yang memberi gambaran tindak pidana perkosaan dalam ketentuan Kitab Undang-undang Hukum Pidana, dimana tindak pidana perkosaan ini adalah suatu bentuk perbuatan tidak saja melanggar aturan-aturan hukum positif akan tetapi juga tidak terlepas dari norma-norma yang hidup dan berkembang di tengahtengah masyarakat 
MUQODDIMAH

\section{Jenis Tindak Pidana Perkosaan Dalam Hukum Pidana}

Setelah menguraikan ketentuan tindak pidana perkosaan pada umumnya yang terdapat dalam hukum pidana yaitu sebagaimana yang terdapat dalam Pasal 285 Kitab Undang-undang Hukum Pidana, berikut ini akan dijelaskan jenisjenis tindak pidana perkosaan yang bersifat khusus seperti di bawah ini :

\section{Perkosaan Wanita Bukan Istri}

Terhadap jenis tindak pidana perkosaan yang diancam hukuman berdasarkan Kitab Undang-undang Hukum Pidana (KUHP) adalah perkosaan kepada wanita yang bukan istri sendiri, dimana ketentuan tindak pidana perkosaan dalam jenis ini diatur dalam Pasal 286 KUHP sebagaimana yang dikemukakan oleh $R$. Sugandhi yaitu : "Barang siapa bersetubuh dengan perempuan yang bukan istrinya, padahal diketahuinya bahwa perempuan itu dalam keadaan pingsan atau tidak berdaya dipidana dengan pidana penjara selama-lamanya sembilan tahun (R. Sugandhi, $1981:$ 303)

2. Perkosaan Di Bawah Umur Selanjutnya tindak pidana perkosaan di bawah umur jenis kejahatan ini adalah perlakuan seksual secara paksa terhadap seseorang wanita yang di bawah umur atau belum pantas dikawini, dimana tindak pidana perkosaan ini sebagaimana diatur di dalam Pasal 287 KUHP sebagaimana yang dikemukakan oleh R. Sugandhi berikut dibawah ini :

Barang siapa bersetubuh dengan perempuan yang bukan istrinya, padahal diketahuinya atau patut disangkanya bahwa umur perempuan itu belum cukup lima belas tahun atau kalau tidak terang umurnya berapa bahwa perempuan itu belum pantas untuk kawin dipidana dengan pidana penjara selama-lamanya sembilan tahun (R. Sugandhi, 1981 : 304).
3. Perkosaan Wanita Belum Pantas Dikawini

Sedangkan untuk tindak pidana perkosaan yang terakhir adalah perkosaan terahdap seseorang wanita yang pada kenyataannya belum pantas untuk dikawini atau dinikahi, ketentuan tindak pidana ini sebagaimana diatur dalam ketentuan Pasal 288 Kitab Undang-undang Hukum Pidana yang dikemukakan oleh R. Sugandhi berikut ini

Barang siapa bersetubuh dengan perempuan yang dinikahinya, padahal diketahuinya atau patut diketahuinya/disangkanya bahwa perempuan itu belum pantas untuk dikawini, dipidana dengan pidana penjara selama-lamanya empat tahun, kalau perbuatan itu berakibat badan perempuan itu mendapat luka.

(R. Sugandhi, 1981 : 305)

Berdasarkan ketiga jenis tindak pidana perkosaan tersebut di atas kiranya jelas terlihat bahwasanya tindak pidana perkosaan ini hanya perbuatan seksual yang dilakukan oleh seorang laki-laki terahdap diri seorang wanita, dimana laki-laki tersebut dalam melakukan kehendaknya untuk bersetubuh dengan cara menggunakan paksaan atau kekerasan. Sedangkan jika dilihat rumusan antara ketentuan Pasal 287 dengan Pasal 288 KUHP adalah mempunyai persamaan yaitu perkosaan yang ditujukan terahdap seseorang wanita di bawah umur, sedangkan perbedaannya dimana ketentuan Pasal 288 KUHP tersebut adalah Pasal pemberatan hukuman yang dijatuhkan terahdap seorang pelaku yang mana hal ini terlihat daria danya unsur badan dari perempuan tersebut mendapat luka. Selanjutnya jika dilihat dalam ketentuan Pasal 288 Kitab Undang-undang Hukum Pidana juga dapat dijatuhkan hukuman terhadap istrinya sendiri, hal ini sebagaimana ditegaskan oleh $R$. 
MUQODDIMAH

Sugandhi seperti berikut ini : "Yang diancam hukuman dengan Pasal ini ialah pria yang ebrsetubuh dengan istrinya padahal diketahuinya atau patut dapat disangkanya bahwa istrinya itu belum pantas dikawini dan jika perbuatan itu mengakibatkan luka (R. Sugandhi, 1981 : 305).

\section{Penentuan Hukuman Terhadap Pelaku Tindak Pidana Perkosaan}

Sebelum menentukan hukuman yang dijatuhkan terahdap pelaku tindak pidana perkosaan terlebih dahulu akan dikemukakan pengertian apa yang dimaksud dengan hukuman, demikian juga ketentuan tentang bentuk tindak pidana perkosaan adalah sebagai delik aduan (Klachdelicten). Sebagaimana yang dikemukakan oleh Sudarto yang dimaksud dengan hukuman sebagai sanksi terhadap akibat dari perbuatan pidana yang dilakukan seseorang pelaku kejahatan itu adalah sebagai berikut di bawah ini :

Penghukuman berasal dari kata hukum, sehingga dapat diartikan sebagai menetapkan hukum atau memutuskan tentang hukumnya (berechten). Menetapkan hukum itu suatu peristiwa tidak hanya menyangkut bidang hukum pidana saja akan tetapi juga hukum perdata.Oleh karena berkisar pada hukum pidana yang kerapkali sinonimnya dengan pemidanaan atau pemberian atau pejatuhan pidana oleh Hakim (Sudarto, 1981:71)

Berdasarkan kata dasar hukum tersebut maka secara harfiahnya hukuman itu berasal dari istialh "Straaf" yang dalam bahasa Indonesia diberi istilah pidana, sejalan dengan hal tersebut maka hukuman ini dapat diartikan sebagai berikut sebagaimana yang dikemukakan oleh P. A. F. Lamintang yaitu :
Alat yang dipergunakan oleh penguasa (Hakim) untuk memperingatkan mereka yang telah melakukan suatu perbuatan yang tidak dibenarkan. Reaksi dari penguasa tersebut telah mencabut kembali dinikmati oleh terpidana atas nyawa kebebasan harta kekayaan yaitu seandainya ia telah melakukan suatu tindak pidana(Sudarto, 1981:13)

Sesuai dengan pendapat sarjana tersebut di atas bilaman suatu tindak pidana dapat dijatuhkan bagi pelaku delik yang utamanya terhadap pelaku tindak pidana perkosaan yang secara paksa, kekerasan maupun dengan ancaman, maka pelaku tindak pidana itu harus dijatuhkan dengan hukuman utamanya yang memberatkan bagi terdakwa

\section{METODE PENELITIAN Lokasi Penelitian}

Sesuai dengan topik dan permasalahan yang dirumuskan dalam penelitian ini maka penulis akan melakukan suatu penelitian atau suatu karya ilmiah seharusnya peneliti harus menentukan dimana lokasi penelitian agar supaya memudahkan bagi penelitian dalam melakukan ataupun dalam mengumpulkan data yang ada kaitannya dengan permasalahan yang diangkat dalam penelitian ini. Sesuai dengan penjelasan penulis tersebut di atas maka lokasi penelitian adalah di pada Pengadilan Negeri Padangsidimpuan, Kantor Advokat yang berada di Kota Padangsidimpuan serta Kantor Kejaksaan Negeri Padangsidimpuan

\section{Pendekatan Penelitian}

Berdasarkan uraian-uraian tersebut di atas selanjutnya penulis menguraikan terlebih dahulu apa pengertian dari pada 


\section{MUQODDIMAH}

penelitian dan sebelum menguraikan bagaimanakah metode penelitian yang akan dilakukan dalam penulisan penelitian ini, sebagaimana menurut pendapat Mohammad Ali adalah : "Suatu cara untuk memahami sesuatu melalui penyelidikan atau usaha mencari buktibukti yang muncul sehubungan dengan masalah itu, yang dilakukan secara hatihati sekali sehingga diperoleh pemecahannya (Mohammad Ali, 2005:13). Sesuai dengan penjelasan tersebut di atas sudah jelas bahwasanya di dalam melakukan penelitian ataupun untuk menyusun suatu karya ilmiah khususnya bagi penulis sendiri yang akan menyusun suatu penelitian yang akan mengakhiri perkuliahan untuk mendapatkan gelar sarjana, maka penulis akan melakukan penelitian riset (Research) yang langsung turun kelapangan.

Selanjutnya tentang pengertian metode penelitian ini sebagaimana yang dikemukakan oleh David H Penny yang mengatakan : "Pemikiran yang sistematis mengenai ilmu pengetahuan yang dijalankan untuk memperoleh fakta-fakta atau prinsip-prinsip dengan sabar, hatihati serta sistematis (David $\mathrm{H}$ Penny, 2002:14). Dengan demikian tentang pendekatan penalitian yang dilakukan dengan cara sebagaimana berikut ini :

a. Penelitian Kepustakaan (Library

Yaitu dengan mengumpulkan data penelitian dengan cara mempelajari buku serta literatur lainnya yang ada hubungannya dengan masalah yang akan diteliti

b. Penelitian Lapangan (Field Research) Yaitu dengan melakukan pengumpulan data langsung terjun kelapangan untuk mengadakan wawancara dengan para responden yang berwenang dalam melakukan pemeriksaan terhadap pelaku tindak pidana pembunuhan hubungan keluarga

\section{Jenis Penelitian Yang Digunakan}

Sesuai dengan penjelasan tersebut di atas dimana Consevela G Sevilla memberikan pengertian Deskriptif adalah : "Metode secara umum mencoba memberikan penjelasan secara menyeluruh tentang suatu obyek untuk memperjelas sebuah kajian tertentu (Consevela G Sevilla, 1993:24). Dengan demikian jenis penelitian yang penulis gunakan dalam penulisan penelitian ini adalah penelitian Normatif yaitu penelitian yang bersumber kepada primer dan skunder berupa peraturan Perundang-undangan dan keputusan Pengadilan Negeri Padangsidimpuan Nomor : 599/Pid.B/2008/PN.Psp.Gnt yang sesuai dengan judul yang diambil dalam penelitian ini

\section{Populasi Dan Sampel Populasi}

Sebelum penulis mengemukakan populasi dalam penelitian ini ada baiknya terlebih dahulu dikemukakan pengertian populasi menurut Sumaharsini Arikunto adalah : "Setiap penelitian senantiasa memiliki objek penelitian dimana keseluruhan objek penelitian ini disebut sebagai populasi (Suharsini Arikunto, 198916). Sesuai dengan penjelasan tersebut di atas maka populasi yang diambil dalam penulisan penelitian ini adalah ; Para Hakim yang berada di Pengadilan Negeri Padangsidimpuan, Advokat dan Para Jaksa pada Kantor Kejaksaan Negri Padangsidimpuan.

\section{Sampel}

Selanjutnya penulis akan mengambil sampel terhadap penelitian ini, akan tetapi terlebih dahulu dikemukakan pengertian sampel seperti yang dijelaskan oleh Sudjana adalah : "Bagian dari populasi yang dipergunakan 
MUQODDIMAH

sebagai sumber data yang sesungguhnya dalam penelitian (Sudjana, 2008:25). Sesuai dengan kutipan tersebut di atas maka penulis akan mengambil sampel sebagai berikut yaitu seorang Hakim Pengadilan Negeri Padangsidimpuan dan seorang Advokat serta Jaksa pada Kantor Kejaksaan Negeri Padangsidimpuan juga Putusan Pengadilan Negeri Padangsidimpuan Nomor 599/Pid.B/2008/PN.Psp.Gnt

\section{Sumber Data}

Sebagai sumber data yang digunakan penulis dalam penelitian ini adalah sebagai berikut :

1. Data Primer adalah suatu data hasil dari pada wawancara pernulsi dengan para responden

2. Data Skunder adalah dimana data ini diambil dari buku-buku atau literatur yang di dalam perpustakaan dan juga Putusan Pengadilan Nomor : 599/Pid.B/2008/PN.Psp.Gnt

\section{Teknik Pengumpulan Data}

Selanjutnya guna untuk mengumpulkan data penelitian akan mempergunakan cara seperti berikut di bawah ini :

1. Wawancara (Interview)

Yaitu dengan melakukan wawancara langsung dengan responden yang telah ditentukan sebelumnya seperti Hakim, Jaksa dan Advokat

2. Studi Dokumentasi

Yaitu dengan mengumpulkan data dari berkas Putusan Pengadilan Negeri Padangsidimpuan Nomor 599/Pid.B/2008/PN.Psp.Gnt

\section{Analisa Data}

Sebagaimana menurut pendapat Sudarto tentang Analisa Data adalah : "Mengolah data dengan menggunakan metode analisis yang dimaksudkan untuk mendapatkan pengetahuan ilmiah dengan mengadakan pemerincian terhadap objek yang diteliti dan menggabungkan beberapa pengertian diharapkan akan di dapatkan pengetahuan baru untuk pemahaman dan kejelasan arti yang dipahami (Sudarto,1997:39-62). Membicarakan analisa data adalah suatu penganalisaan terhadap data-data yang terkumpul baik yang di dapat dari hasil wawancara dan yang terdapat di dalam suatu dokumen yang berkaitan dengan permasalahan yang dirumuskan dalam penelitian dengan menggunakan cara :

1. Induksi yaitu mengelola data dari fakta yang bersifat khusus untuk mengambil suatu kesimpulan pada hal yang bersifat umum

2. Deduksi yaitu mengolah data dari fakta yang bersifat umum untuk mengambil suatu kesimpulan pada hal yang bersifat khusus

\section{PEMBAHASAN \\ Faktor Yang Memberatkan Hukum Terhadap Pelaku Tindak Pidana Perkosaan}

Pertanggung jawaban hukuman terahdap pelaku tindak pidana perkosaan pada dasarnya adalah merupakan pertanggung jawaban yang bersifat khusus, karena sebagaimana ditegaskan dalam penentuan pertimbangan hukuman bahwa tindak pidana perkosaan itu erat kaitannya dengan kepentingan masyarakat yang perlu dilindungi oleh hokum. Dikatakan demikian disebabkan penuntutan terhadap tindak pidana perkosaan dengan secara kekerasan, paksaan dan ancaman yang berkelanjutan dengan adanya ancaman bagi saksi korban adalah merupakan delik aduan yang artinya perbuatan seperti ini tidak akan dilakukan penuntutan jika sebelumnya tidak ada pengaduan dari pihak yang korban ataupun pihak yang dirugikan

Sehubungan dengan itulah seperti yang ditegaskan oleh Hakim Pengadilan 


\section{MUQODDIMAH}

Negeri Padangsidimpuan bahwa masalah dapat tidaknya pelaku tindak pidana perkosaan terhadap yang bukan istri terdakwa yang syah adalah tergantung dari keinginan pihak korban apakah merasa keberatan jika samalah ini diajukan terhadap pemeriksaan persidangan Pengadilan. Demikian juga jika ditinjau dari tindak pidana perkosaan terhadap orang yang bukan istrinya telah diproses di sidang Pengadilan masalah hukuman tidak lagi tergantung atas perbuatannya apakah dijatuhkan ringan atau berat akan tetapi menurut penegasan Jaksa Penuntut Umum pada Kantor Kejaksaan Negeri Padangsidimpuan dimana persoalan ini sepenuhnya adalah wewenang dari Hakim yang memeriksanya, maka oleh sebab itulah sebagaimana yang diberlakukan dalam ketentuan hukum pidana dalam menjatuhkan serta memperberat hukuman terhadap pelakunya tetap dilaksanakan sesuai dengan mestinya

Adapun yang dapat dijadikan sebagai faktor untuk menerapkan hukuman dengan alasan diperberat selain yang telah ditetapkan dalam Putusan Pengadilan Negeri Padangsidimpuan Nomor, 599/Pid.B/2008/PN. Psp. Gnt tersebut jika dilihat dari akibat perbuatan terdakwa yang telah mengakibatkan kerugian bagi korban dan juga menjadi pemicu perselisihan antara pihak keluarga korban dan pihak keluarga terdakwa serta membuat keresahan bagi masyarakat umum. Kemudian disamping itu juga dapat dijadikan sebagai faktor untuk memperberat hukuman dari terdakwa adalah unsur kesengajaan yang dilakukan secara berkelanjutan dan ancaman serta paksaan sebagaimana yang terdapat dalam kasus tersebut di atas secara tegas dinyatakan bahwa perlakuan terdakwa Ismail Parapat Alias Lautan yang memperkosa seorang wanita yang bukan istrinya ataupun bukan dilakukan atas dasar suka sama suka akan tetapi perlakuan perkosaan itu terdakwa lakukan dengan cara kekerasan dan ancaman. Dengan penjelasan tersebut di atas dimana apabial adanya unsur paksaan dapat dibuktikan dengan cara terdakwa melakukan tindak pidana perkosaan tersebut yaitu dengan kekerasan serta ancaman untuk mempermudah niatnya melakukan tindak pidana perkosaan tersebut sehingga sebagai korban jelas berada dipihak yang tidak berdaya, karena perbuatan yang dilakukan terdakwa dalam memperkosa seorang perempuan yang bukan istrinya dapat diidentik dengan suatu perbuatan yang tidak manusiawi. Selanjutnya faktor lain yang dijadikan sebagai alasan dalam memperberat hukuman terhadap pelaku tindak pidana perkosaan adalah perbuatan terdakwa yang dilakukan secara berulang-ulang yang mana dalam pengakuan terdakwa tidak mengakui perbuatannya itu akan tetapi pihak korban maupun saksi yang memberikan keterangannya dimuka persidangan Pengadilan dimana terdakwa telah melakukan perkosaan itu terhadap saksi korban Maria sebanyak 5 kali sesuai dengan Putusan Pengadilan Negeri Padangsidimpuan Nomor, 599/Pid.B/2008/PN. Psp. Gnt

Berdasarkan penjelasan tersebut di atas oleh karena itu sebagaimana yang ditegaskan oleh seorang advokat dengan perbuatan terdakwa yang dilakukan secara berulang-ulang sesuai keterangan para saksi-saksi maupun saksi $A$ de Charge dan juga alat bukti sebilah pisau dapur yang bergagang kayu serta dengan diajukannya bukti surat dari saksi ahli yaitu Visum Et Repertum Nomor 445/575/VII/RSUDGT/2008 tanggal 26 Juli 2008 atas nama saksi korban Maria yang ditanda tangani oleh Dr. $\mathrm{H}$. Naga Bakti Harahap di muka persidangan 


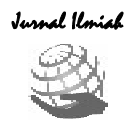

\section{MUQODDIMAH}

Pengadilan Negeri Padangsidimpuan biarpun terdakwa membantah keterangan tersebut Hakim berkeyakinan adanya unsur perencanaan setiap akan melakukan tindak pidana perkosaan tersebut baik perencanaan mengenai waktunya maupun perencanaan mengenai cara melakukannya. Sesuai dengan uraian tersebut di atas kiranya demikianlah faktor yang dapat dijadikan untuk memperberat hukuman bagi terdakwa jika dilihat dari korban yang bernama Maria yang merasa trauma akibat dari perbuatan terdakwa Ismail Parapat Alias Lautan dimana terdakwa melakukan perbuatannya itu dengan adanya ancaman kekerasan dan berkelanjutan terhadap saksi korban yang bukan istrinya sendiri, maka dengan demikian sebagaimana yang terdapat di dalam ketentuan Pasal 285 Jo Pasal 64 Kitab Undang-undang Hukum Pidana bahwasanya terdakwa sudah dapat dijatuhi dengan hukuman yang berat dengan hukuman penjara selama-lamanya delapan tahun enam bulan

Selanjutnya sebagaimana juga yang dijelaskan oleh Hakim Pengadilan Negeri Padangsidimpuan dengan menyebutkan bahwa perbuatan terdakwa tersebut adalah telah melanggar norma kesusilaan yang dapat dikategorikan sebagai perbuatan pemerkosaan terhadap yang bukan istrinya sehingga sesuai dengan fakta peristiwa yang terungkap bahwa terdakwa telah terbukti melakukan delik secara berkelanjutan terhadap saksi korban Maria. Berdasarkan seluruh uraian-uraian tersebut di atas demikianlah faktor yang dapat dijadikan untuk memperberat hukuman terhadap pelaku tindak pidana perkosaan yang mana secara teoritisnya bahwa faktor tersebut dapat dibagi menjadi dua bagian yaitu intren yang termasuk alasan-alasan yang bersifat kepentingan pribadi atau keluarga sedangkan faktor ekstren adalah yang berkaitan dengan alasan memperberat hukuman

\section{Pertimbangan Hakim Menetukan Hukuman Terhadap Pelaku Tindak Pidana Perkosaan}

Dalam memberikan pertimbangan hukuman terhadap pelaku tindak pidana perkosaan adalah suatu peristiwa yang tidak hanya melanggar norma-norma hukum akan tetapi juga dimana perbuatan tersebut telah melanggar norma kesusilaan, maka oleh sebab itu perbuatan perkosaan dalam bentuk seperti ini dikatakan sebagai delik khusus atau yang sering disebut sebagai Speciale Delicten yang terdapat di dalam hukum pidana.

Selanjutnya adapun yang merupakan pertimbangan Hakim untuk mengklasifikasikan jenis tindak pidana perkosaan ini adalah sebagai delik khusus menurut Hakim Pengadilan Negeri Padangsidimpuan menjelaskan bahwa acara pembuktian yang dilakukan seharusnya di lakukan di depan persidangan seperti halnya dengan mengajukan saksi-saksi dan alat-alat buki serta mengajukan hasil visum et repertum yang dikeluarkan oleh dokter. Sebagaimana penjelasan tersebut di atas gambarannya telah jelas terlihat di dalam Putusan Pengadilan Negeri Padangsidimpuan Nomor 599/Pid.B/2008/PN.Psp. Gnt dimana dalam penelitian yang mana dijadikan saksi-saksi yaitu Maria sebagai saksi korban, Misni, Pitri $\mathrm{Br}$ Hasibuan, Indah $\mathrm{Br}$ Harahap dalah putri dari saksi korban serta Halim Harahap adalah suami dari saksi korban dan juga di dalam persidangan dihadirkan saksi yang namanya saksi $A$ De Charge antara lain adalah Dahlan Parapat, Tongku Malim Parapat dan Binah serta di dukung dengan Visum Et Repertum 445/575/VII/RSUDGT/2008 tanggal 26 
Juli 2008 atas nama saksi korban Maria yang ditanda tangani oleh $\mathrm{Dr}$. $\mathrm{H}$. Naga Bakti Harahap. Sesuai dengan itu pula sifat tindak pidana perkosaan yang sesuai dengan Putusan Pengadilan Negeri Padangsidimpuan Nomor 599/Pid.B/2008/PN. Psp. Gnt ini adalah merupakan perbuatan yang fakta hal ini sebagaimana yang dijelaskan oleh seorang advokat bahwa persidangan dalam hal tindak pidana perkosaan ini disidangkan secara tertutup karena yang menjadi dasar pertimbangan bagi Hakim nantinya adalah dilatar belakangi adanya tindakan ancaman, kekerasan, paksaan yang dilakukan secara berkelanjutan dan juga ini adalah merupakan salah satu tindak pidana yang tidak boleh diketahui oleh masyarakat umum biarpun pada hasilnya nanti dapat ketahui oleh masyarakat umum

Kemudian untuk proses pembuktian sebagai dasar bagi Hakim untuk mengambil suatu pertimbangan hukum yang pertama dan yang terpenting adalah adanya pengetahuan dari terdakwa hal ini sesuai dengan yang terdapat di dalam Putusan Pengadilan Negeri Padangsidimpuan Nomor 599/Pid.B/2008/PN. Psp. Gnt telah jelas sebagai dasar pertimbangan pertama oleh Hakim adalah seluruh keterangan saksi-saksi yang diajukan kemuka persidangan serta dengan dihadirkannya juga saksi $A$ De Charge yang mengatakan bahwa terdakwalah yang telah melakukan pemerkosaan terhadap saksi korban yang bernama Maria yang bukan istrinya sendiri sebanyak lima kali sesuai dengan Visum Et Reprtum Nomor 445/575/VII/RSUDGT/2008 tanggal 26 Juli 2008 atas nama saksi korban Maria yang ditanda tangani oleh $\mathrm{Dr}$. $\mathrm{H}$. Naga Bakti Harahap dan juga dengan mempertimbangkan alat-alat bukti yang diajukan yaitu 1 (satu) bilah pisau belati ataupun pisau dapur bergagang kayu
Dengan demikian apabila kita lihat dari pendapat seorang Jaksa Penuntut Umum pada Kantor Kejaksaan Negeri Padangsidimpuan yang mengatakan bahwa pembenaran dan pengingkaran terdakwa atas terhadap seluruh keterangan saksi-saksi yang diajukan baik dari saksi $A$ De Charge tersebut dan juga dengan adanya alat bukti yang dipergunakan untuk mengancam saksi korban Maria di atas adalah merupakan suatu penggarisan bagi Hakim telah ada suatu perbuatan melanggar hukum yang dilakukan oleh terdakwa secara berkelanjutan dengan ancaman terhadap saksi korban Maria sebagaimana yang terdapat di dalam ketentuan Pasal 285 dan Jo Pasal 64 Kitab Undang-undang Hukum Pidana dapat dibuktikan kebenarannya. Sesuai dengan penjelasan Jaksa tersebut di atas maka dasar adanya perbuatan melakukan tindak pidana perkosaan terhadap saksi korban Maria yang bukan istri terdakwa dengan secara kekerasan, paksaan dimana perbuatannya itu berkelanjutan adalah merupakan asalan penjatuhan hukuman yaitu yang dalam ketentuan Pasal 285 Kitab Undang-undang Hukum Pidana dikenakan pidana penjara selama-lamanya dua belas tahun sebab dengan adanya perbuatan berkelanjutan dan adanya ancaman yang sesuai dengan ketentuan Pasal 64 Kitab Undang-undang Hukum Pidana, maka yang dijatuhkan hukuman terdakwa itu dengan hukuman yang terberat sesuai dengan hukuman utamanya

Seterusnya di dalam tindak pidana perkosaan ini juga yang akan menjadi pertimbangan Hakim akibat yang telah timbul terhadap saksi korban dimana perbuatan terdakwa tersebut benarbenar telah merusak kepercayaan dan merusak hubungan keluarga dengan suaminya serta juga di dalam hubungan antara sesama masyarakat dimana saksi korban merasa malu untuk berhadapan 


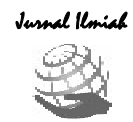

\section{MUQODDIMAH}

dengan masyarakat banyak hal ini sesuai dengan penjelasan Hakim Pengadilan Negeri Padangsidimpuan ini adalh merupakan dasar pertimbangan untuk kepentingan korban sebagai manusia yang berhak atas perlindungan hokum. Masalah lain yang dapat dijadikan pertimbangan Hakim untuk menentukan hukuman terhadap pelaku tindak pidana perkosaan adalah ditinjau dari unsur kesalahan yang telah diperbuat terdakwa dimana seperti dijelaskan tidak adanya rasa keganjilan dalam diri terdakwa saat melakukan perkosaan yang secara berkelanjutan tersebut terhadap saksi korban Maria yang pada dasarnya bukan istrinya yang sah akan tetapi adalah istri orang lain. Berdasarkan penjelasan tersebut di atas di dalam Putusan Pengadilan Negeri Padangsidimpuan Nomor, 599/Pid.B/2008/PN. Psp. Gnt tersebut oleh advokat menyebutkan dinyatakan suatu pertimbangan yang berbunyi bahwa benar sewaktu melakukan persetubuhan ataupun tindak pinda perkosaan terahdap saksi korban Maria tersebut terdakwa tidak ada memikirkan akibatnya walaupun saksi koran itu bukan istrinya sendiri. Dengan demikian secara yuridis apabila ditinjau dari sikap terdakwa dalam melakukan tindak pidana perkosaan terhadap saksi korban itu merupakan dasar pertimbangan bahwa Hakim berkewajiban untuk menjatuhkan hukuman yang berat bagi terdakwa dan ini dijadikan sebagai kesimpulan bagi terdakwa untuk dikenakan hukuman yang bersifat pidana penjara.

Selanjutnya menurut Hakim Pengadilan Negeri Padangsidimpuan bahwa dari sikap yang diperbuat terdakwa adalah sebagai alasan untuk meminta meminta pertanggung jawaban atas perbuatannya dan pertanggung jawaban tersebut direalisaksikan dengan menentukan hukuman bagi terdakwa sesuai dengan pelanggar hukum yang telah dilakukannya. Dengan demikian dimana seluruh uraian tersebut di atas tergambar bahwasanya terhadap penentuan hukuman atas tindak pidana perkosaan ini sepenuhnya di dasarkan dalam perbuatan terdakwa terhadap saksi korban baik hal itu mengenai saksisaksi maupun alasan-alasan lain yang dijadikan sebagai dasar untuk mempertimbangkan bagaimana hukuman yang akan dijatuhkan bagi diri terdakwa

\section{Hambatan Penentuan Hukuman Terhadap Pelaku Tindak Pidana Perkosaan}

Berdasarkan keseluruhan ulasan dalam menentukan hukuman serta faktor memperberat hukuman terhadap suatu tindak pidana perkosaan yang bukan istrinya ternyata bukan merupakan persoalan yang mudah dalam mempertimbangkannya apabila terdakwa membantah seluruh dari pada keterangan saksi-saksi maupun saksi dari saksi $A$ De Cahrge, dikatakan demikian sebab jika ditinjau dari ancaman yang semestinya diajtuhkan berdasarkan Pasal 285 Kitab Undangundang Hukum Pidana selama dua belas tahun dan juga sebagaimana yang terdapat dalam ketentuan Pasal 64 Kitab Undang-undang Hukum Pidana yang menyatakan bahwa apabila suatu perbuatan yang diteruskan walaupun masing-masing perbuatan itu menjadi kejahatan atau pelanggaran maka hukuman yang akan dijatuhkan terhadap terdakwa adalah hukuman utamanya ataupun hukuman yang memberatkan sebagaimana yang terdapat di dalam Putusan Pengadilan Negeri Padangsidimpuan Nomor. 599/Pid.B/2008/PN. Psp. Gnt terdakwa dijatuhi dengan hukuman penjara selama-lamanya delapan tahun enam bulan. Sehubungan dengan itu pada kenyataannya menunjukkan masih 


\section{MUQODDIMAH}

adanya hambatan dalam penerapan hukuman terhadap pelaku tindak pidana perkosaan di dalam praktek, maka dengan demikian untuk memberat hukuman inipun dalam keadaanya yang belum begitu sepenuhnya dilaksanakan sebagaimana yang ditentukan dalam ketentuan Pasal 64 Jo Pasal 65 Kitab Undang-undang Hukum Pidana dengan penambahan sepertiga dari hukuman pokok yang terberat

Berdasarkan penjelasan tersebut di atas sebagaimana yang dikemukakan oleh Hakim Pengadilan Negeri Padangsidimpuan bahwa hambatan tersebut sebenarnya tidak terlepas dari sulitnya dalam melakukan pembuktian atas tindak pidana perkosaan terhadap orang yang bukan istrinya yang mana oleh fakta kejadian berada dalam ancaman terdakwa terhadap saksi korban dan saksi korbanpun merasa takut untuk memberitahukannya kepada pihak keluarga atau yang berwenang menyebabkan kurangnya data-data untuk mengambil suatu kesimpulan

Selanjutnya Jaksa Penuntut Umum pada Kantor Kejaksaan Negeri Padangsidimpuan menjelaskan tentang penentuan saksi-saksi yang harus diperiksa di sidang Pengadilan yang diharapkan mengungkapkan perbuatan terdakwa dengan sebenarnya akan tetapi ada juga yang menutup-nutupi perbuatan terdakwa itu sendiri sebab mereka mengetahuinya hanya dari keteranganketerangan dari orang lain sebab mungkin saja terdakwa adalah pemuka agama ataupu tokoh adat di dalam masyarakat. Sehingga kondisi demikian Hakim sebagai aparat yang bertugas menggali setiap kebenaran dalam kasus seperti ini tidak dapat berbuat banyak apalagi dalam persidangan sering terjadi tangisan-tangisan yang membuat para saksi tidak terkontrol dalam memberikan kesaksiannya. Sedangkan hambatan lainnya yang juga dapat mempengaruhi penjatuhan hukuman terhadap pelaku tindak pidana perkosaan adalah masih besarnya ketergantungan terhadap keluarga terdakwa sehingga bilamana terdakwa dijatuhkan hukuman sebagaimana yang diatur dalam ketentuan hukum pidana justru akan menambah kesulitan bagi Hakim untuk menambah hukuman dari hukuman yang sebenarnya. Berdasarkan penjelasan tersebut di atas bila dikaitkan dengan persoalan di atas sebagaimana yang dijelaskan oleh seorang advokat kendala ini terus mempengaruhi jalannya musyawarah Hakim dalam menentukan hukuman terhadap terdakwa sehingga menyebabkan Hakim Majelis sering berbeda pendapat untuk menentukan tinggi rendahnya hukuman yang akan dijatuhkan. Sedangkan alasan lain yang menjadi hambatan dalam menentukan hukuman terhadap pelaku tindak pidana perkosaan adalah dengan tidak jelasnya cara terdakwa dalam melakukan tindak pidana perkosaan tersebut apalagi terdakwa membantah semua keterangan saksi-saksi yang diajukan di muka persidangan dan juga disebabkan keterangan para saksi hanya bersifat pengakuan saja seperti pengakuan dari saksi korban sedangkan terdakwa adalah sebagai pihak yang langsung terlibat. Apabila dikaitkan dengan penjelasan tersebut di atas dimana hanya keterangan saksi saja yang dipertimbangkan dan tidak dipertimbangkan hal-hal yang lain sementara saksi tidak melihat secara langsung terjadinya tindak pidana perkosaan yang dilakukan terdakwa, maka apabila Hakim hanya bertahan terhadap keterangan yang bersifat pengakuan saja secara Hukum Acara Pidana tidak berkekuatan hukum, melainkan pengakuan tersebut harus didukung dengan keterangan saksi lainnya serta alat-alat bukti yang digunakan dalam melakukan tidan 


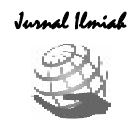

\section{MUQODDIMAH}

pidana tersebut. Dengan demikian adapun penyebab dari semua hambatan tersebut di atas adalah tidak terlepas dari kurangnya fakta yang terungkap saat melakukan penyidikan apar Kepolisian yang mana seperti dijelaskan di atas biasanya dalam kasus-kasus yang seperti ini aparat penyidik hanya memfokuskan penyidikannya dengan cara melakukannya sebab di dalam penentuan suatu perkara oleh Jaksa Penuntut Umum biasanya adalah tidak terlepas dari latar belakang kejadian maka untuk mengetahui latar belakang ini akan lebih mudah bagi Hakim dalam menentukan pertanggung jawaban hukum kepada pelaku tindak pidana perkosaan.

\section{KESIMPULAN DAN SARAN Kesimpulan}

Adapun bebrapa kesimpulan yang dapat diambil dari hasil penelitian ini adalah sebagai berikut :

a. Bahwa faktor yang memberatkan hukuman terhadap pelaku tindak pidana perkosaan di Pengadilan Negeri Padangsidimpuan apabila kita lihat dari tindakan pelaku tersebut seharusnya hukuman tersebut seharusnya diberikan dengan hukuman yang memberatkan, seperti faktor adanya unsure paksaan dari pelaku, unur ancaman dan unsure kekerasan, maka untuk memberatkan hukuman tersebut seharusnya dihukum sesuai dengan Undangundang yang berlaku sebagaimana yang terdapat dalam Putusan Pengadilan Negeri Padangsidimpuan Nomor, $\quad$ 599/Pid.B/2008/PN.Psp dimana pelaku dapat dihukum dengan 8 (delapan) tahun dan 6 (enam) bulan penjara

b. Bahwa pertimbangan Hakim untuk menentukan hukuman terhadap pelaku tindak pidana perkosaan tidak terlepas dari kepentingan masyarakat sekalipun pelaku telah berbuat salah dan juga untuk memberikan hukuman berat terhadap pelaku tindak pidana perkosan belum dapat diterapkan sebagaimana mestinya karena

\section{Saran}

Adapun saran yang penulis ajukan dalam penelitian ini adalah sebagai berikut di bawah ini :

a. Mengingat tindak pidana perkosaan yang terlalu bersifat pribadi hendaknya penyidangan kasus seperti ini dilakukan lebih teliti khususnya dalam pemeriksaan saksisaksi yang sedianya adalah dalam hubungan keluarga, dan juga tindak pidana perkosaan ini adalah merupakan bentuk delik perencanaan kiranya Hakim tidak perlu terlalu berpegang kepada kepentingan keluarga dari pada kepentingan penerapan hukumnya

b. Mengingat besarnya resiko dan tidak manusiawinya perbuatan perkosaan ini semestinya hukuman dijatuhkan dengan menrapkan alasan memperberat yang dengan adanya penambahan sepertiga dan juga dalam pengungkapkan peristiwa hendaknya penyidik sebagai awal proses epradilan kiranya dotongkatkan teknik pemeriksaan dengan tidak mengabaikan latar belakang kejadian sebagai faktor terjadinya

\section{DAFTAR PUSTAKA}

A. Zainal Abidin, 1986, Hukum Pidana, Prapanca, Jakarta

Abdulsyani, 1987, Sosiologi Kriminal, Remaja Karya, Bandung

A. S. Pudjoharsoyo, 1993, Varia Peradilan, Ikatan Hakim Indonesia, Jakarta

Consevela G Sevilla, 1993, Metode Deskriptif, UI, Press, Jakarta 
MUQODDIMAH

Darmansyah Hasibuan, 1980, Pokokpokok Hukum Pidana, Fakultas Hukum USU, Medan

David H Penny, 2002, Metodologi Penelitian, Grafindo, Jakarta

D. Soedjono, 1983, Pemeriksaan Pendahuluan Menurut KUHAP, Alumni, Bandung

H. A. K. Moch Anwar, 1989, Hukum Pidana Bagian Khusus (KUHP Buku II), Citra Aditya, Bandung

Hermien Hadiati Koeswadji, 1989, Kejahatan Terhadap Nyawa, Azasazas Kasus dan Permsalahannya, Sinar Wijaya, Surabaya

J. E. Sahetapy, 1991, Kapita Selekta Hukum Pidana, Alumni, Bandung

Kartini Kartono, 1981, Patologi Sosial, Rajawali, Jakarta

Mohammad Ali, 2005, Metodologi Penelitian, Rajawali, Jakarta

Moelyatno, 1992, Kitab Undang-undang Hukum Pidana, Yigyakarta

P. A. F. Lamintang, 1979, Hukum Pidana Indonesia, Sinar Baru, Bandung

R. Soesilo, 1974, Hukum Pidana (KUHP) Serta Komentarkomentarya Lengkap Pasal Demi Pasal, Politeia, Bogor

R. Sugandhi, 1981, Kitab Undangundang Hukum Pidana Dengan Penjelasannya, Usaha Nasional, Surabaya

Sumadi Suryabrata, 1983, Metodologi Penelitian, Rajawali, Jakarta

Sumadi Suryabrata, 1981, Metodologi Penelitian, Usaha Nasional, Surabaya
Suharsini Arikunto, 1989, Metode Penelitian, Politeia, BogorSudjana, 2008, Metodologi Penelitian, Sinar Grafindo, Grafindo, Jakarta

Sudarto, 1981, Kapita Selekta Hukum Pidana, Alumni, Bandung

Kitab Undang-undang Hukum Pidana

Kitab Undang-undang Hukum Acara Pidana 